\title{
Food of Our Future Grows from Seeds of Our Past
}

\author{
Staff at Kua'āina Ulu 'Auamo
}

"Food sovereignty" is an increasingly used term in Hawai' $i$, but many may not know its origin, meaning, or application to our community. First developed in 1996 by La Via Campesina-an international movement of rural people-the Declaration of Nyéléni at the first global forum on food sovereignty in Mali, Africa in 2007 defines it this way:

Food sovereignty is the right of peoples to healthy and culturally appropriate food produced through ecologically sound and sustainable methods, and their right to define their own food and agriculture systems. It puts the aspirations and needs of those who produce, distribute and consume food at the heart of food systems and policies rather than the demands of markets and corporations.

Food security concerns itself with food access in the conventional transnational context. Undergirded by ecological and human rights for all, food sovereignty recognizes a local right to determine and transform one's own food systems. Over 2,500 miles from anywhere, Hawai'i has many unique reasons to see food sovereignty as a response to the precarious dependency of our current food system. Eighty-five to ninety percent of our food is imported. Much of it is processed and of low nutritional value. The COVID-19 pandemic makes our food system challenges glaringly obvious. As we rebuild, concern grows over whether the government and current food systems can address these challenges. As with care for our greater environment, it might be better if a vision and cultural shift in our food systems starts from the ground up, with Hawai'i's people.

Indigenous and local culture and history can guide us. Prior to Western contact, Hawai'i was food self-sufficient, supporting a population estimated to be close to one million people, almost as many as the 2010 US Census estimation of 1.365 million. Today, a traditional Hawaiian diet, made up of seafood and traditional crops such as taro and sweet potato, is a recognized contributor to improved health, especially for Native Hawaiians who experience health disparities per capita. We see pathways in the rigorous epistemology of pre-Western Hawai' $\mathrm{i}$, which many in our communities work to carry forward today. It offers a very different relationship to our food, places, communities, politics, and each other. 


\section{Hawaiian Food Sovereignty of the Past: 'Āina Momona}

Native Hawaiians developed food, environmental stewardship, customs, and traditions and expertise based on intimate knowledge and long-term multigenerational ecological observations. Traditional food systems produced a resource surplus that exceeded population needs. True on the land and in the sea, this state is referred to as 'äina momona, an abundant productive ecological system that supports community well-being. Food sovereignty is part and parcel of seeking 'aina momona. Hawai 'i's people and biocultural resources-storied landscapes, sacred forests, agroforests, streams and rivers, agricultural fields, fisheries, fishponds, and reefs-are deeply damaged by over 200 years of political, economic, and social upheaval and change. Rarely do people, even residents, understand Hawai' i's historic and ongoing role in the US campaign of influence in the Pacific and Asia, or the consequences of colonization on Native Hawaiians. Few know of the historical erosion of Native Hawaiian governance, the overthrow of the internationally recognized Hawaiian Kingdom, the post-overthrow policies to wipe out Native Hawaiian language, culture, and identity, or the historical and ongoing severance of relationships and familial connections to ancestral lands and the natural world.

But not all is lost, nor were Native Hawaiians idle in the last two centuries. In the lessons learned from the past lies a path toward a better future. Prior to the overthrow, Native Hawaiians developed an evolving governance system that integrated community and resource management practices for 'anina (referred to then as the ahupua'a or moku system), and 'āina-based leadership embodied in leaders called konohiki. Leadership with a konohiki mindset connected better with and involved communities to care and govern their place. Hawaiians also became one of the world's most literate populations, entered into treaties with other nation-states, and published books on history, tradition, and culture still used today. In preserving a sense of cultural and national identity, they planted seeds for future generations to reconnect with each other, their culture, their places, and even the world. Those seeds germinate today.

The ongoing Native Hawaiian movement emerging from the 1960-79 renaissance based its attendant values, customs, and practices on the foundations left by previous generations. This traditional ecological knowledge (TEK) includes cultural legacies retained by 'ohana and individual kūpuna (elders), kumu (knowledge sources), kahu (guardians), kāhuna (priests), and loea (experts and professionals) who preserved traditions through practice or oral history.

\section{Hawaiian Food Sovereignty of the Future}

Because of such threats as the current COVID-19 pandemic, climate change, sea-level rise, natural disasters, and labor issues such as shipping or airline strikes, Hawai'i must move away from dependency on imported goods which make up ninety percent of our food. To achieve food sovereignty, we must draw upon our community spirit and Hawai 'i's TEK. 
Three community movements in Hawai'i ground their actions and advocacy in the idea that "I ka wā ma mua, ka wā ma hope," the future continues from the path laid behind us. Each effort bridges people to place through a community-based biocultural resource management strategy to restore nearshore fisheries, loko i'a (fishponds), a traditional aquaculture practice and the celebration, stewardship, and restoration of native limu (seaweed).

\section{Community-based Subsistence Fishing Areas (CBSFA)}

In 1994, Hawai' $i$ policymakers passed the CBSFA law (HRS 188-22.6) inspired by the konohiki practices of Mo'omomi, Moloka'i, and Governor Waihe'e's Moloka'i Subsistence Task Force to reaffirm and protect fishing practices customarily and traditionally exercised for purposes of Native Hawaiian subsistence, culture, and religion. Government leadership took almost twenty years to pass the first CBSFA rules in Hā'ena, Kaua'i. Today three other communities are in the queue for rulemaking: Mo'omomi, Moloka'i; Kipahulu, Maui; and Miloli'i, Hawai'i island. These communities work together in the spirit of lawai'a pono to fish virtuously, to fish Hawaiian, and to care for their fisheries.

\section{Loko I'a}

Found nowhere else in the world, ancient Hawaiian loko i'a were a technologically advanced, efficient, and extensive form of aquaculture. Indicators of 'āina momona, they provided much of the protein in the traditional Native Hawaiian diet, and retain the potential to contribute to healthy and robust food systems and fisheries. Over recent decades, Hawaiian communities and kia'i loko (fishpond guardians and caretakers) worked to restore loko i'a and reclaim the knowledge and practice of loko i'a culture. Recognizing shared challenges to increase collaboration and accelerate restoration and food production, kia'i loko from six Hawaiian Islands formed the Hui Mālama Loko I'a, a network of loko i'a and kia i loko. Since 2004, Hui Mālama Loko I'a has met annually to strengthen relationships and share experience and expertise.

\section{Limu}

Limu had a significant role in many aspects of Hawaiian culture and 'āina momona. Nowhere else in the world was limu used as extensively. Hawaiian people gathered it for food, medicine, and spiritual purposes. Along with fish and poi, limu was the third major component of a healthy traditional diet by providing flavor and key vitamins and minerals.

Revival and perpetuation of TEK and connections to limu will also develop the biocultural systems that limu depends upon, and that depend upon limu. To carry out this crucial pathway to 'āina momona, a new, burgeoning, and multigenerational movement formed the Limu Hui. 


\section{Building Movement Networks for Community Resilience}

Kua'āina Ulu 'Auamo (KUA) means "grassroots growing through shared responsibility." KUA — or "backbone"-gathers, organizes, mobilizes, and supports community-based natural resource management networks - communities, practitioners, families, individuals, and organizations - who work to perpetuate TEK and build a stronger sense of local governance and empowered management of place. KUA reinvigorates sentiments and traditions of laulima, aloha 'āina, and mālama 'āina as embodied in TEK and its attendant values, ethics, and regional place-based practices. KUA's community-driven approach supports E Alu Pū, a network of thirty-six mālama 'āina (natural and cultural resource stewardship) groups, Hui Mālama Loko I'a, a consortium of over forty fishponds and fishpond complexes, and the Limu Hui, a network of native seaweed gatherers, growers, and stewards.

The waiwai (value) of Hawai' $i$ lies in its people and brings them together to work towards 'āina momona. E Alu Pū, Hui Mālama Loki I'a, and Limu Hui efforts have sprouted the seeds left by our kūpuna. They can teach, guide, and spearhead this work; however, the true revival of our loko i'a, limu, fisheries, wahi pana, and ahupua'a depends on the development of a whole community. Food sovereignty is an ecosystem of which we are all a part. Every Hawai'i resident and visitor has a function. How will you activate your role? What seeds will you plant today? It will take a whole community to move us away from our current corporate and foreign food overdependency and toward more sustainable livelihoods and food systems.

\section{Work Cited}

Declaration of Nyéléni. Declaration of the Forum for Food Sovereignty, Nyéléni, Mali, 27 Feb. 2007.

This essay is the collective mana'o of Kua'äina Ulu 'Auamo staff derived from numerous conversations on this subject.

Kevin Chang and Miwa Tamanaha, Co-Directors, Kua'āina Ulu 'Auamo

Brenda Asuncion, Hui Malama Loko I'a Coordinator

Alex Connelly, E Alu Pū Coordinator and Program Assistant

Ginger Gohier, Community Outreach and Engagement Coordinator

Wally Ito, Limu Hui Coordinator

Kim Moa, Communications Coordinator

Lauren Muneoka, Program Associate and Technical Specialist

Niegel Rozet, Planner 